Rapp. Grønlands geol. Unders. 99, 121-128 (1980)

\title{
GEOCHEMICAL AND ORE MICROSCOPIC \\ INVESTIGATIONS ON DRAINAGE SANDS FROM THE PEARY LAND REGION, NORTH GREENLAND
}

\author{
M. Ghisler and H. Stendal
}

\section{Introduction}

This study is part of a regional geochemical survey based on stream sediment samples collected in the summers of 1978 (fig. 55) and 1979 (cf. Henriksen, this report). The purpose of the present work is a first attempt to delineate areas or geological units, which may contain mineral deposits. A description of the geological setting, known mineralisations, sampling method, laboratory procedures and presentation of preliminary results is given by Ghisler et al. (1979). The stratigraphical division used is based on results published in 'Report of the 1978 geological expedition to the Peary Land region, North Greenland, Rapp. Grønlands geol. Unders. no. 88' and in papers by Collinson (this report) and Jepsenet al. (this report). The stratigraphical units are indicated on Table 6.

The mineralogical investigations comprise ore microscopic studies of 235 polished sec-

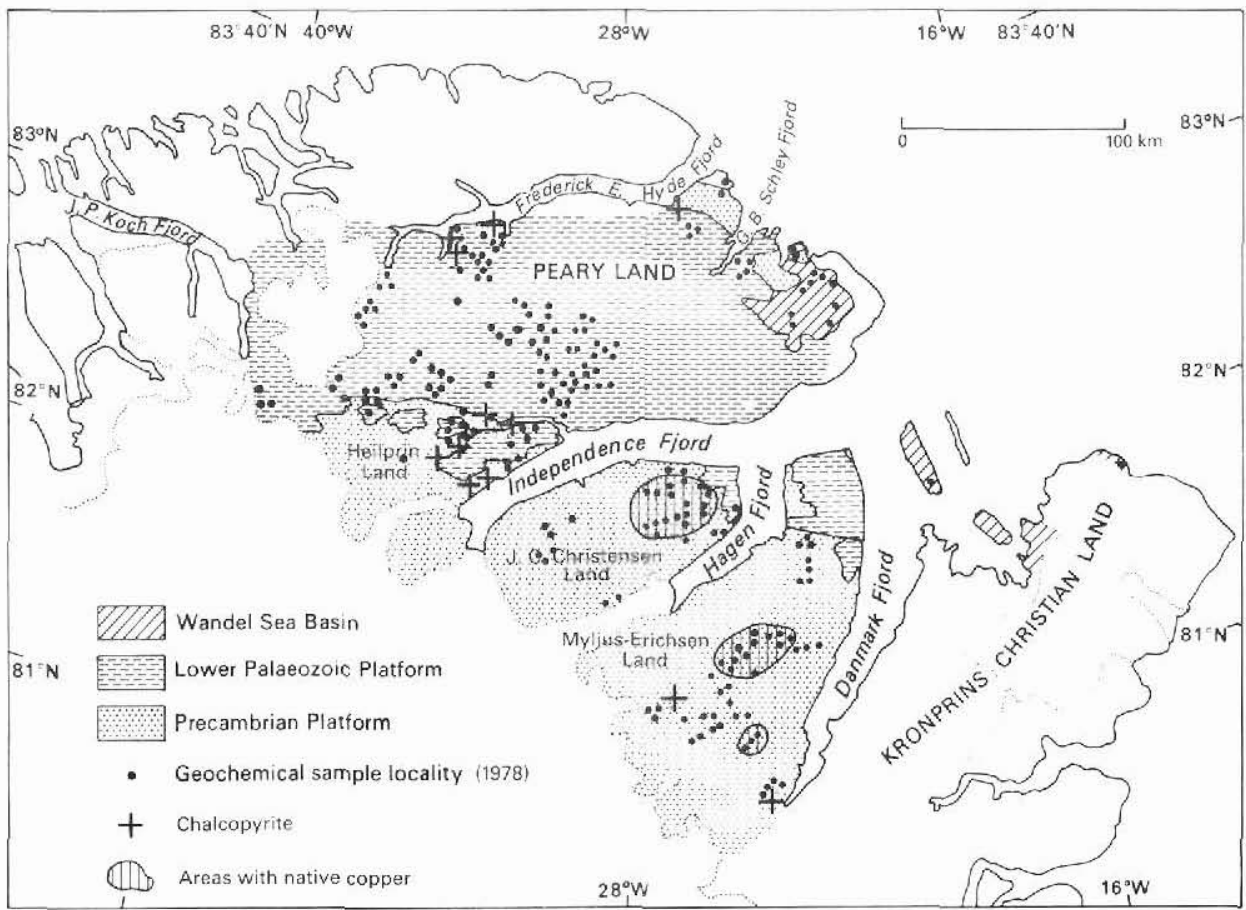

Fig. 55. Sketch map showing the distribution of geochemical sample localities (1978) as well as copper anomalies in sand samples. 
Table 6. Distribution of native copper and sulphides in polished sections of heavy mineral concentrates

\begin{tabular}{|c|c|c|c|c|c|c|c|c|c|c|c|c|c|c|}
\hline & & & & 紊: & & & & nber $\mathrm{c}$ & f san & iples & cont & ining & & \\
\hline & Stratigraphy & Area & 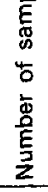 & 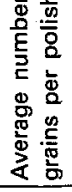 & 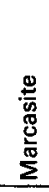 & 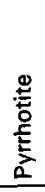 & 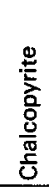 & 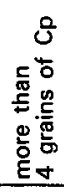 & $\begin{array}{l}\frac{0}{5} \\
\frac{\Phi}{0} \\
0\end{array}$ & $\begin{array}{l}\frac{\mathscr{g}}{5} \\
\frac{5}{5} \\
\frac{\pi}{5} \\
\text { के }\end{array}$ & 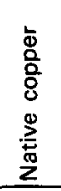 & 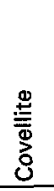 & 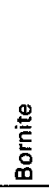 & 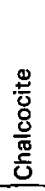 \\
\hline : & $\begin{array}{l}\text { Wandel Sea B } \\
\text { Silurian units }\end{array}$ & $\begin{array}{l}\text { N.E.Peary Land } \\
\text { S. of Fr. E. Hyde Fi. }\end{array}$ & $\begin{array}{r}4 \\
11\end{array}$ & $\begin{array}{r}30 \\
620\end{array}$ & $\begin{array}{l}2 \\
2\end{array}$ & & 8 & 3 & 1 & & & & & \\
\hline 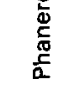 & $\begin{array}{l}\text { Brønlund Fj. Gp } \\
\text { \& Buen Fm } \\
\text { Portfjeld Fm }\end{array}$ & $\begin{array}{l}\text { Central Peary Ld } \\
\& \text { N.E. Peary Land } \\
\text { Mainly Heilprin Ld }\end{array}$ & $\begin{array}{r}7 \\
18\end{array}$ & $\begin{array}{l}370 \\
220\end{array}$ & 13 & & 10 & 2 & 1 & 1 & & & 1 & \\
\hline 产 & $\begin{array}{l}\text { Campanuladal } \\
\text { Formation } \\
\text { Morænes } \varnothing \mathrm{Fm}\end{array}$ & $\begin{array}{l}\text { Mylius-Erichsen Ld } \\
\text { J.C.Christensen Ld } \\
\text { Heilprin Land }\end{array}$ & $\begin{array}{r}10 \\
8 \\
5\end{array}$ & $\begin{array}{l}40 \\
35 \\
50\end{array}$ & $\begin{array}{l}2 \\
2 \\
5\end{array}$ & & $\begin{array}{l}5 \\
4 \\
5\end{array}$ & $\begin{array}{l}1 \\
1\end{array}$ & & & 2 & & & \\
\hline 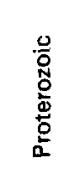 & $\begin{array}{l}\text { Zig-Zag Dal } \\
\text { Basalt Fm } \\
\\
\text { Independence } \\
\text { Fjord Group }\end{array}$ & $\begin{array}{l}\text { Mylius-Erichsen Ld } \\
\text { J.C.Christensen Ld } \\
\text { N.E.Peary Land } \\
\text { Mylius-Erichsen Ld } \\
\text { J.C.Christensen Ld } \\
\text { Heilprin Land }\end{array}$ & $\begin{array}{r}13 \\
18 \\
3 \\
12 \\
9 \\
12\end{array}$ & $\begin{array}{r}4 \\
8 \\
\text { n.d. } \\
5 \\
10 \\
14\end{array}$ & $\begin{array}{l}1 \\
2 \\
2\end{array}$ & 2 & $\begin{array}{r}8 \\
10 \\
2 \\
7 \\
6 \\
10\end{array}$ & $\begin{array}{l}1 \\
1\end{array}$ & $\begin{array}{l}1 \\
1\end{array}$ & 1 & $\begin{array}{r}7 \\
14\end{array}$ & $\begin{array}{l}2 \\
5\end{array}$ & 1 & 1 \\
\hline
\end{tabular}

Number of sand samples 130 .

tions prepared from 133 heavy mineral concentrates of the sand samples collected in 1978 , as well as examination under ultra-violet light of all samples. The geochemical study concerns chemical analyses of the Fe-Mn oxide coatings of 129 samples of raw drainage sands (collected in 1978) in order to indicate areas with high concentrations of $\mathrm{Cu}$ and $\mathrm{Zn}$.

\section{Ore microscopy}

Iron-titanium oxides are the most abundant opaque minerals of nearly all heavy mineral concentrates, of which they form, on average, 25-30 per cent by weight. They occur in varying amounts and in different relative proportions. The iron-titanium oxides are in order of decreasing amounts: titanomagnetite, magnetite, hematite, ilmenite and rutile. No quantitative work on the oxide minerals was undertaken, but the microscopic study has shown the following distribution:

Titanomagnetite (magnetite with ilmenite lamellae) and to a certain extent magnetite are the most abundant oxides in samples from the Proterozoic sandstones (Independence Fjord Group, cf. Collinson, this report) and dolerites throughout the region. Titanomagnetite is dominant in samples derived from the Zig-Zag Dal Basalt Formation (Jepsen et al., this report) in Mylius-Erichsen Land, whereas hematite generally dominates in the basalt area of J. C. Christensen Land. In samples from the Eocambrian and Phanerozoic areas hematite 
generally dominates, and rutile takes over a more prominent role. Ilmenite is present in nearly all samples, but only in a few cases as a dominant constituent.

Chromite is found in 35 per cent of all samples either as a few individual grains or as inclusions in silicates. The main portion occurs in the samples from the Proterozoic terrains, where the dolerites, more frequently than the basalts, provide chromite. In samples from the Phanerozoic sediments chromite is absent or only scarcely represented. The folded Silurian rocks south of Frederik E. Hyde Fjord have yielded some samples containing chromite.

Sulphides are widespread, but their content in the polished sections only rarely exceeds that of the oxide minerals. The following sulphides are identified in order of decreasing amounts: pyrite, chalcopyrite, marcasite, covellite, galena, pyrrhotite, sphalerite, bornite and chalcocite. The distribution of native copper and sulphide minerals in relation to stratigraphic units, as well as to areas of origin, is presented in Table 6.

Pyrite, often more or less altered to limonite, is by far the most common and most abundant sulphide mineral, and is observed in 84 per cent of all samples. The number of grains varies considerably from only a few to several thousands per polished section. The Proterozoic areas consisting mainly of sandstones, dolerites and basalts are comparatively poor in pyrite, which means 5-10 grains per section, and with maximum figures of some 50 grains. Sands from Heilprin Land show the highest contents. Distinctly higher pyrite contents occur in the sands from the Eocambrian formations. Of particular interest is framboidal pyrite (fig. 56), which makes its first appearance at this stratigraphic level in samples from the multicoloured members of the Campanuladal Formation (Clemmensen, 1979). Framboidal structures are hereafter common in samples from the whole Phanerozoic sequence, commonly preserved as limonite framboids with relict pyrite cores. Increasing amounts of pyrite (several hundred grains) are found throughout the Palaeozoic sequence, reaching a maximum in the Silurian flysch sediments.

Marcasite occurring mainly as an alteration product of pyrite, is rather scarce throughout the region. High contents, up to 1500 grains per section are, however, found in samples from the Buen Formation of north-east Peary Land. A few grains or inclusions of pyrrhotite occur in four polished sections from the Proterozoic areas.

Chalcopyrite is present in nearly 60 per cent of all samples, but the number of grains in each polished section rarely exceeds one to three grains, which corresponds to the background level of the area. Samples with more than 4 grains are regarded as anomalous. Their distribution and stratigraphic position is given in fig. 55 and Table 6. The most distinctive anomaly is found in the multicoloured members of the Campanuladal Formation at the southern end of Danmark Fjord. Two polished sections contain, respectively, 58 and 32 chalcopyrite grains up to $0.4 \mathrm{~mm}$ in size, associated with ten times as much framboidal pyrite (fig. 56). Three samples with anomalous chalcopyrite contents originate from the Silurian flysch (in one case associated with shales) south of Frederick E. Hyde Fjord. As many as six chalcopyrite-rich samples representing a stratigraphic section from the upper Independence Fjord Group to the Portfjeld Formation are found in Heilprin Land.

Galena was observed in four samples as a single grain in each sample or, in one case, as inclusions in pyrite. Sphalerite was identified in two samples, in one case associated with galena.

Native copper is found in 67 per cent of the samples originating from the Zig-Zag Dal Basalt Formation in Mylius-Erichsen Land and J. C. Christensen Land. It occurs as small inclusions in silicate grains, probably epidote. The inclusions are mostly only a few microns 


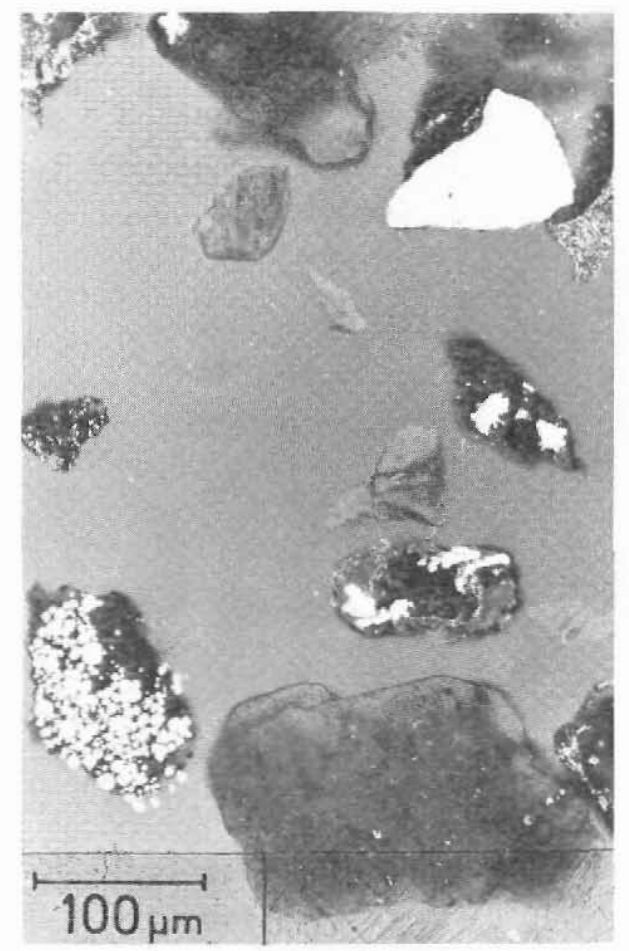

Fig. 56. Pyrite framboid (lower left) and chalcopyrite (upper right) in sand from the Multicoloured members of the Campanuladal Formation. Reflected light.

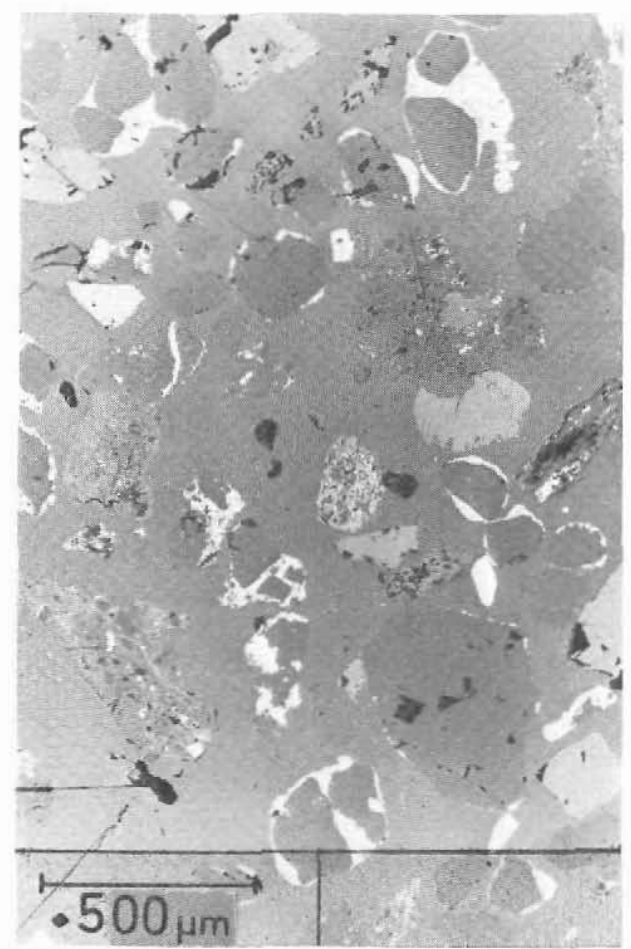

Fig. 57. Limonite coating (white) in sand sample from the Portfjeld Formation, Heilprin Land. Reflected light.

in size, but inclusions $10-15 \mu \mathrm{m}$ across are not uncommon and may reach a maximum of 40 $\mu \mathrm{m} .80$ per cent of the samples originating from central J. C. Christensen Land contain native copper (fig. 55), in five cases associated with covellite and in one case in addition with bornite. From Mylius-Erichsen Land 54 per cent of the samples from the basalts in two areas contain native copper (fig. 55), two of which are accompanied by covellite. In addition to the occurrences of native copper in the samples derived from the basalts, native copper was found in two samples from the Campanuladal Formation in north-east J. C. Christensen Land. In one of these samples, native copper occurs as inclusions in a silicate grain, which forms part of a limonite-cemented, 'conglomeratic' rock fragment. This grain is obviously derived from the underlying basalts and has become incorporated in the silty to sandy sediments of the multicoloured members.

The examination of the heavy mineral concentrates under ultra-violet light did not reveal any fluorescent economic minerals such as scheelite except zircon, which is widespread and abundant. 


\section{Geochemical investigations}

The application of Fe-Mn oxide coatings on detrital grains of drainage sediments as a sample medium in geochemical exploration for various metals, has been described and discussed recently by several authors (Whitney, 1975; Carpenter et al., 1975; Chao \& Theobald, 1976; Nowlan, 1976; and Carpenter \& Hayes, 1979). The successful application of this method is based on the fact that secondary mobilised heavy metals, such as $\mathrm{Zn}$ and $\mathrm{Cu}$, are concentrated (scavenged) in minerals belonging to the $\mathrm{Fe}-\mathrm{Mn}$ oxide/hydroxide group. All the papers mentioned deal with areas where hydromorphic dispersion patterns are well known. As shown by this investigation and by Stendal (1979), in North Greenland under arctic conditions the chemical resistance is comparatively high for many sulphide minerals, which elsewhere are decomposed rapidly. Therefore the hydromorphic dispersion is generally supposed to be low. But some phenomena of hydromorphic dispersion halos are reported from arctic areas with permafrost. The most common visible features are malachite staining near copper sulphide mineralisation and limonite formation due to the weathering of iron sulphides. Tedrow (1970) has described the formation of soils in Inglefield Land, western North Greenland, and Washburn (1969) reports that chemical weathering is locally important in East Greenland. Based on the study of sulphide deposits in the arctic of the Soviet Union, Ivanov (1966) also concluded that chemical weathering does take place even in frozen rock.

The microscopic study on the heavy mineral concentrates of drainage sands from the Peary Land region has shown that limonite coatings on mineral grains do occur and are widespread (fig. 57). Based on these observations and the experience from the mentioned literature, $\mathrm{Fe}-\mathrm{Mn}$ oxide coatings were tested for their scavenging effect on $\mathrm{Cu}$ and $\mathrm{Zn}$ and their possible use to indicate areas with anomalous concentrations of these metals. It is not possible at the present stage to determine whether the coatings so analysed were precipitated recently or during earlier geological periods.

The raw sand samples, which are those that yielded the heavy mineral concentrates, were sieved to minus $250 \mu \mathrm{m}$, and $0.5 \mathrm{~g}$ of the sieved material was leached for half an hour following the procedure described by Whitney (1975). The leaching reagent is $0.3 \mathrm{M}$ ammonium citrate with 2 per cent $w / v$ hydroxylamin hydrochloride which does not react significantly with either the most common silicates, or carbonates, or sulphides. The solution obtained was analysed by a Perkin Elmer 460 Atomic Absorption Spectrophotometer for $\mathrm{Fe}, \mathrm{Mn}, \mathrm{Cu}$ and $\mathrm{Zn}$. Background corrector was used and the standards were matched as closely as possible to the samples in reagent as well as metal concentrations.

The most important results, including some statistical parameters, are presented in Table 7. The average $\mathrm{Zn}$ content is nearly double that of the $\mathrm{Cu}$ content. The average $\mathrm{Mn}$ content is twice that of $\mathrm{Fe}$, due to the analytical leaching procedure (Whitney, 1975). Mn shows a very high standard deviation. In order to eliminate 'false' $\mathrm{Zn}$ and $\mathrm{Cu}$ anomalies, due to the concentration effect of the varying amounts of $\mathrm{Fe}$ and $\mathrm{Mn}$, the ratios of metal/Fe, metal/Mn and metal/ $\mathrm{Fe}+\mathrm{Mn}$ have been calculated for $\mathrm{Cu}$ and $\mathrm{Zn}$, respectively, for each sample. Only the average values are given in Table 7 . It is seen that both the ranges and contrasts (peak/threshold) are higher for $\mathrm{Zn}$ than for $\mathrm{Cu}$, which reflect the relative mobilities of these two metals. The coefficient of determination $\left(r^{2}\right)$, which indicates the quality of fit achieved by the regression, are calculated for all samples and for two populations separately (Table 8). The best correlation is found between $\mathrm{Zn}$ and $\mathrm{Zn} / \mathrm{Fe}+\mathrm{Mn}$. There is no correlation 
Table 7. Statistical parameters and geochemical variation of $\mathrm{Fe}, \mathrm{Mn}, \mathrm{Cu}$ and $\mathrm{Zn}$ in Fe-Mn oxide coatings in the minus $250 \mu \mathrm{m}$ fraction of raw sand samples $(N=$ 129)

\begin{tabular}{|c|c|c|c|c|c|}
\hline & $\begin{array}{l}\text { Arithmetic } \\
\text { mean }\end{array}$ & $\begin{array}{l}\text { Standard } \\
\text { deviation }\end{array}$ & Range & $\begin{array}{c}\text { Threshold } \\
\text { (mean }+2 \text { st.dev.) }\end{array}$ & $\begin{array}{c}\text { Contrast } \\
\text { (peak/thresh.) }\end{array}$ \\
\hline $\mathrm{Fe}$ & $57 \mathrm{ppm}$ & 44 & $9-210 \mathrm{ppm}$ & 145 ppm & 1.45 \\
\hline $\mathrm{Mn}$ & 103 ppm & 140 & $2-684 \mathrm{ppm}$ & 383 ppm & 1.79 \\
\hline $\mathrm{Cu}$ & $1.9 \mathrm{ppm}$ & 1.6 & $0.1-11.3 \mathrm{ppm}$ & $5.1 \mathrm{ppm}$ & 2.22 \\
\hline $\mathrm{Zn}$ & $3.2 \mathrm{ppm}$ & 3.9 & $0.1-29.7 \mathrm{ppm}$ & $11.0 \mathrm{ppm}$ & 2.70 \\
\hline $\mathrm{Cu} / \mathrm{Mn} \times 100$ & 4 & 5 & $1-30$ & 14 & 2.14 \\
\hline $\mathrm{Zn} / \mathrm{Mn} \times 100$ & 8 & 15 & $1-100$ & 38 & 2.63 \\
\hline $\mathrm{Cu} / \mathrm{Fe} \times 100$ & 5 & 4 & $1-20$ & 13 & 1.54 \\
\hline $\mathrm{Zn} / \mathrm{Fe} \times 100$ & 9 & 14 & $1-107$ & 37 & 2.89 \\
\hline $\mathrm{Cu} /(\mathrm{Fe}+\mathrm{Mn}) \times 100$ & 2 & 1.5 & $1-9$ & 5 & 1.80 \\
\hline $\mathrm{Zn} /(\mathrm{Fe}+\mathrm{Mn}) \times 100$ & 4 & 6.3 & $1-51$ & 16 & 3.19 \\
\hline
\end{tabular}

between $\mathrm{Cu}$ and $\mathrm{Cu} / \mathrm{Mn}$ and between $\mathrm{Cu}$ and $\mathrm{Cu} / \mathrm{Fe}+\mathrm{Mn}$. A fairly good correlation between $\mathrm{Fe}$ and $\mathrm{Mn}$ is found for all populations, but no correlation exists between $\mathrm{Cu}$ and $\mathrm{Zn}$.

Among the $\mathrm{Zn} / \mathrm{Fe}+\mathrm{Mn}$ values five anomalies are found, all belonging to samples from population 2. Two very distinct anomalies originate from the Independence Fjord Group in Mylius-Erichsen Land and J. C. Christensen Land, respectively, and two anomalies from Heilprin Land. One anomalous value belongs to the Zig-Zag Dal Basalt Formation in J. C. Christensen Land.

\section{Discussion}

The sand samples contain, beside the common resistant heavy minerals, a number of unaltered sulphide minerals and native copper. Chalcopyrite and galena were already known to occur in concentrates from drainage sands in East Greenland (Stendal, in press), but the presence of minerals such as covellite, bornite, chalcocite and native copper in the heavy mineral concentrates indicates an even lower degree of chemical weathering in the Peary Land region, which is designated an arctic desert.

The most significant results from the microscopic investigation are the copper anomalies found in different areas and at several stratigraphic levels. Chalcopyrite occurs in many samples from the Independence Fjord Group, where mineralisation is reported in several places, mainly close to dolerite dykes (Ghisler et al., 1979). In general, however, this geological unit must be regarded as of rather limited interest owing to the small extent of possible deposits. The occurrences of native copper in the sands reflect the extent of the Zig-Zag Dal Basalt Formation. The content of sulphide minerals in these samples is, however, extremely low, and accordingly the chances of finding copper sulphide concentrations within the volcanics appear small.

The pyrite-rich sediments overlying the basalts represent the most promising host rocks for copper sulphide deposits. A very distinct anomaly is already known for the multicoloured members. The occurrence of native copper in a silicate fragment from this stratigraphic level suggests that the source rocks, for at least paft of these sediments, are the $\mathrm{Cu}$-bearing 
Table 8. Coefficients of determination $\left(r^{2}\right)$ in two populations of sediments from the Peary Land region

\begin{tabular}{lcccccc}
\hline & $\begin{array}{c}\mathrm{Cu} \text { to } \\
\mathrm{Cu} / \mathrm{Mn} \times 100\end{array}$ & $\begin{array}{c}\mathrm{Cu} \text { to } \\
\mathrm{Cu} / \mathrm{Fe}+\mathrm{Mn} \times 100\end{array}$ & $\begin{array}{c}\mathrm{Zn} \text { to } \\
\mathrm{Zn} / \mathrm{Mn} \times 100\end{array}$ & $\begin{array}{c}\mathrm{Zn} \text { to } \\
\mathrm{Zn} / \mathrm{Fe}+\mathrm{Mn} \times 100\end{array}$ & $\mathrm{Fe} / \mathrm{Mn}$ & $\mathrm{Cu} / \mathrm{Zn}$ \\
\hline $\begin{array}{l}\text { Phanerozoic } \\
\quad \&\end{array}$ & 0.01 & 0.36 & 0.003 & 0.30 & 0.48 & 0.15 \\
$\begin{array}{l}\text { Eocambrian } \\
\text { (57 samples) }\end{array}$ & 0.06 & 0.14 & 0.71 & 0.77 & 0.45 & 0.00 \\
$2 \begin{array}{l}\text { Proterozoic } \\
\text { (72 samples) }\end{array}$ & 0.03 & 0.19 & 0.28 & 0.63 & 0.47 & 0.00 \\
$\begin{array}{l}\text { Whole area } \\
\text { (129 samples) }\end{array}$ & & & & & & \\
\hline
\end{tabular}

Population 1: Phanerozoic sediments and Eocambrian sediments above the Zig-Zag Dal Basalt Formation. Population 2: Independence Fjord Group and Zig-Zag Dal Basalt Formation

basalts. The necessary supply of sulphur for the formation of copper sulphide deposits is present, as reflected by the numerous grains of bacterial pyrite framboids. Similar occurrences of framboidal pyrite are known from the Eleonore Bay Group in East Greenland, where they appear in bed 3 of the Quartzite Series, which contains several stratabound copper mineralised horizons (Ghisler et al., 1980). Not only the Campanuladal Formation, but also the Morænesø Formation west of the basalt area contains distinct copper indications, found both in the field (malachite) and in the polished sections of the sands (chalcopyrite).

The presence of chalcopyrite in sands from the area south of Frederick E. Hyde Fjord probably originates from the sulphide mineralisation associated with an east-west fracture lineament (Schack Pedersen, personal communication).

The geochemical analyses indicate that $\mathrm{Fe}$ and $\mathrm{Mn}$ show a consistant correlation in the two sample populations (Table 8). This suggests similar leaching of $\mathrm{Fe}$ and $\mathrm{Mn}$ by circulating waters independent of bedrock geology. The best correlation is found between $\mathrm{Zn}$ and $\mathrm{Zn} / \mathrm{Fe}+\mathrm{Mn}$, and also the best contrast (peak/threshold) is found for $\mathrm{Zn} / \mathrm{Fe}+\mathrm{Mn}$ (Table 7). The latter result is in accordance with the conclusions obtained by Carpenter \& Hayes (1979). There seems, however, to be no correlation between $\mathrm{Cu}$ and $\mathrm{Cu} / \mathrm{Mn}$ and between $\mathrm{Cu}$ and $\mathrm{Cu} / \mathrm{Fe}+\mathrm{Mn}$ (Table 8). This suggests that $\mathrm{Cu}$ is not available in the secondary environment in sufficient amounts to become scavenged in the Fe-Mn coatings.

\section{Conclusions}

1. Because of the very low degree of chemical weathering, the ore microscopic study of heavy mineral concentrates from drainage sands appears to be an adequate method in reconnaissance geochemical exploration for mineral deposits in this region.

2. The analysis of Fe-Mn oxide coatings in the sands may be a useful tool in the search for areas enriched in zinc, whereas no significant results are obtained for copper. 
3. The most promising stratigraphic units as host rocks for copper sulphide deposits throughout the region are the Campanuladal and Morænesø Formations.

4. On the basis of the 1978 samples, the most significant anomalies outline the following areas to be of special interest for more detailed investigations:

(a) The area of Heilprin Land with respect to copper and partly zinc comprising the upper part of the Independence Fjord Group, Morænesø Formation and Portfjeld Formation.

(b) The basalt areas in central J. C. Christensen Land with respect to occurrences of native copper, as well as the contact areas to younger sediments in J. C. Christensen Land and Mylius-Erichsen Land with respect to copper sulphide deposits.

(c) The fold belt south of Frederick E. Hyde Fjord with respect to copper sulphides.

\section{References}

Carpenter, R. H. \& Hayes, W. B. 1979: Fe-Mn oxide coatings in routine geochemical surveys. In Watterson \& Theobald (edit.) Geochemical Exploration 1978. Proc. 7th int. Geochem. explor. symp. Golden, Colorado. 277-282.

Carpenter, R. H., Pope, T. A. \& Smith, R. L. 1975: Fe-Mn oxide coatings in stream sediment geochemical surveys. J. geochem. Explor. 4, 349-363.

Chao, T. T. \& Theobald, P. K. 1976: The significance of secondary iron and manganese oxides in geochemical exploration. Econ. Geol. 71, 1560-1569.

Clemmensen, L. B. 1979: Notes on the palaeogeographical setting of the Eocambrian tillite-bearing sequence of southern Peary Land, North Greenland. Rapp. Gronlands geol. Unders. 88, 15-22.

Ghisler, M. Henriksen, N., Steenfelt, A. \& Stendal, H. 1979: A reconnaissance geochemical survey in the Proterozoic-Phanerozoic platform succession of the Peary Land region, North Greenland. Rapp. Grønlands geol. Unders. 88, 85-91.

Ghisler, M., Jensen, Aa., Stendal, H. \& Urban, H. 1980: Stratabound copper mineralization in the late Precambrian of the East Greenland Caledonides. In Janković, S. \& Sillitoe, R. H. (edit.) The European copper deposits. Spec. Publ. Soc. Geol. Appl. Miner. Deposits 1, 160-165.

Ivanov, O. P. 1966: Basic factors in the development of sulfide deposit oxidation zones under permafrost conditions. Geokhimiya, 1095-1105, (In Russian). Translation: Geochem. Intern. 3, 875-884.

Nowlan, G. A. 1976: Concretionary manganese-iron oxides in streams and their usefullness as a sample medium for geochemical prospecting: J. geochem. Explor. 6, 1/2, 193-210.

Stendal, H. 1979: Geochemical copper prospecting by use of inorganic drainage sediment sampling in central East Greenland. Trans. Instn Min. Metall. B 88, B1-B4.

Stendal, $H$. (in press): Distribution of metals and heavy minerals in drainage sediments in late Precambrian rocks of central East Greenland $\left(72-74^{\circ} \mathrm{N}\right)$. Proceedings from Trondheim Symposium, Sept. 1979. Norges Geologiske Undersøkelse, Special Volume.

Tedrow, J. C. F. 1970: Soil investigations in Inglefield Land, Greenland. Meddr Grønland 188(3), 93 p.

Washburn, A. L. 1969: Weathering, frost action, and patterned ground in the Mesters Vig district, northeast Greenland. Meddr Grønland 176(4), 303 p.

Whitney, P. R. 1975: Relationship of manganese-iron oxides and associated heavy metals to grain size in stream sediments. J. geochem. Explor. 4, 251-264. 